\title{
Sacituzumab Govitecan and Treatment Area
}

\author{
Mine Ün (1), Özge Çoşkun (1)
}

\section{Antibody Drug Conjugates}

Antibody drug conjugates have been studied for nearly 30 years, but early samples failed due to incorrect selection of antigen targets. For this reason, an antigen found in tumor cells was wanted to be selected and in this way it was aimed to reduce toxicity. ${ }^{[1-3]}$ These conjugates are drugs that select cancer cells in a specific way and have toxic effects on these cells. Due to its selectivity, it has high effect and less toxic effect on healthy body cells. ${ }^{[4]}$

Antibody drug conjugates (ADCs); It consists of an antibody, a cytotoxic agent and a synthetic binding chemical that binds the two together. The main factor in the use and effectiveness of these drugs is the antigen that the antibody will act on. These antigens must be recognized and bound by the antibody, expressed less in normal cells and overexpressed in tumor cells. The cytotoxic drugs used here are small molecular weight chemicals to stop cell division and affect different points. ${ }^{[4]}$

These newly developed therapeutic agents have been tried in many cancer treatments and some of them have received FDA approval. ${ }^{[4]}$ Antibody Drug conjugates (ADCs) are used in the treatment of Hodgkin lymphoma, systemic anaplastic large cell lymphoma, human epidermal growth factor receptor 2

Istanbul Aydın University Medical Faculty, Istanbul, Turkey

Correspondence: Mine Ün. İstanbul Aydın Üniversitesi Tıp Fakültesi, 34295 Sefaköy, Küçükçekmece, İstanbul, Türkiye.

E-mail: unmine13@gmail.com

Cite this article as: Ün M, Çoşkun Ö. Sacituzumab Govitecan and Treatment Area. JEB Med Sci 2020;1(2):62-64.

doi: $10.5606 /$ jebms.2020.75613

Received : September 05, 2020

Accepted : September 28, 2020

Published online : November 09, 2020

๑2020 Journal of Experimental and Basic Medical Sciences. All rights reserved.

\section{ABSTRACT}

Although there are diagnosis and treatment methods for cancer, treatment methods for metastatic cancers are limited. Therefore, new treatments for metastatic cancer are being investigated. Antibody drug conjugates (ADCs) are a new group of drugs that enable highly toxic drugs to be targeted. Sacituzumab govitecan is a second-generation antibody drug conjugate that is promising with its results in many cancer treatment trials.

Keywords: Sacituzumab govitecan, TROP2.

(human epidermal goeth factor receptor 2 [HER2]) positive metastatic breast cancers, and studies are ongoing for their use in the treatment of some hematopoietic and solid tumors. ${ }^{[5-8]}$

\section{SACITUZUMAB GOVITECAN}

Sacituzumab govitecan (IMMU-132) is a moderately effective antiTROP2 antibody drug conjugate. ${ }^{[4]}$ It consists of the combination of SN-38, the active molecule of irinotecan, and an antibody targeting the TROP2 receptor. $^{[3]}$

Irinotecan is a topoisomerase inhibitor effective in lung, gastrointestinal and gynecological cancers. ${ }^{[1,9]}$ During mitosis, cells stop dividing by affecting the $S$ phase. ${ }^{[3]}$ It is metabolized in the liver and excreted from the intestines, so the most common side effect is diarrhea. ${ }^{[1]}$

TROP2 (Trophoblast cell surface antigen 2) is a glycoprotein marker located on the trophoblastic cell surface that transmits cell survival and division signals, discovered in trophoblast cells in the placenta. Trophoblasts provide the attachment and invasion of the placenta to the uterus. ${ }^{[10,11]}$ In this context, TROP2 is thought to play a role in cell division, cancer invasion, metastasis and angiogenesis. ${ }^{[12,13]}$ It is also found in some healthy tissues in the body, but; It is expressed at much higher levels in cancer cells compared to 
normal epithelial cells. At the same time, the risk of cancer development and metastasis increases with the increase of TROP2 expression. ${ }^{[3]}$ This makes TROP2 a unique target in cancer therapy. ${ }^{[10,14,15]}$

\section{TREATMENT AREAS OF SACITUZUMAB GOVITECAN}

Sacituzumab govitecan has been shown to be effective in many types of cancer such as breast cancer, urothelial carcinoma, gastrointestinal cancers, small cell lung cancer and non-small cell lung cancer, and is predicted to be used in cancer treatment due to its low toxicity. Studies are still ongoing and it is thought that it can be used in metastatic cancers that cannot be treated in the near future. ${ }^{[3]}$

Urothelial carcinoma is the fifth most common malignant disease in the United States, with a rate of $90-95 \%$ occurring in the transitional epithelium in the lower urinary tract (bladder, urethra). In 2017, 79,030 new urothelial carcinomas were diagnosed in the USA, and 16,890 people died of urothelial carcinoma in 2017. ${ }^{[16-18]}$ Cisplatin-based combination therapies are mainly used in the treatment of metastatic urothelial carcinoma. This treatment provides a 13-16 month survival in patients who are applied. ${ }^{[19-21]}$ However, response to treatment is $20 \% .^{[22]}$

Breast cancer is the most common cancer in women worldwide. ${ }^{[23]}$ Treatment rate is increasing day by day in breast cancers diagnosed early. ${ }^{[24]}$ However, treatment may not be possible in metastatic breast cancers despite new treatment methods. ${ }^{[25]}$

Sacituzumab govitecan is used in the treatment of metastatic breast cancers that are HER2 (human epidermal goeth factor receptor 2) positive. Sacituzumab treatments are given by intravenous infusion. There are 8, 10, 12, $18 \mathrm{mg} / \mathrm{kg}$ dose options in the treatment of both urothelial and breast cancer, but the best effect was seen at a dose of $12 \mathrm{mg} / \mathrm{kg}$. Administration of antiemetic and anticholinergic drugs to the patient to prevent infusion reactions does not hinder the treatment. ${ }^{[26]}$ The most common side effects are: fatigue, hair loss, nausea, diarrhea and neutropenia.

Resistance to antibody drug conjugates can also be seen. Although the reason for this resistance is not fully understood, it is thought that factors such as personal metabolization and differences in the properties of tissues, incomplete antigen-antibody binding in some patients reduce the effect of the drug and reduce the success of the treatment. ${ }^{[4,27]}$
In conclusion, Sacizutumab govitecan has safe and therapeutic activity in metastatic solid cancer types. Low toxic effects and diarrhea were observed in its side effects. Its use with combined drugs is promising in cancer treatment. ${ }^{[28]}$

\section{Declaration of conflicting interests}

The authors declared no conflicts of interest with respect to the authorship and/or publication of this article.

\section{Funding}

The authors received no financial support for the research and/or authorship of this article.

\section{REFERENCES}

1. Goldenberg DM, Cardillo TM, Govindan SV, Rossi EA, Sharkey RM. Trop-2 is a novel target for solid cancer therapy with sacituzumab govitecan (IMMU132), an antibody-drug conjugate (ADC). Oncotarget 2015;6:22496-512.

2. Starodub AN, Ocean AJ, Shah MA, Guarino MJ, Picozzi VJ Jr, Vahdat LT, et al. First-in-Human Trial of a Novel Anti-Trop-2 Antibody-SN-38 Conjugate, Sacituzumab Govitecan, for the Treatment of Diverse Metastatic Solid Tumors. Clin Cancer Res 2015;21:3870-8.

3. Sahota S, Vahdat LT. Sacituzumab govitecan: an antibodydrug conjugate. Expert Opin Biol Ther 2017;17:1027-31.

4. Lee EK, Liu JF. Antibody-drug conjugates in gynecologic malignancies. Gynecol Oncol 2019;153:694-702.

5. deGoeijBE,Lambert JM. New developments for antibodydrug conjugate-based therapeutic approaches. Curr Opin Immunol 2016;40:14-23.

6. Gravanis I, Tzogani K, van Hennik P, de Graeff P, Schmitt $P$, Mueller-Berghaus J, et al. The European Medicines Agency Review of Brentuximab Vedotin (Adcetris) for the Treatment of Adult Patients With Relapsed or Refractory CD30+ Hodgkin Lymphoma or Systemic Anaplastic Large Cell Lymphoma: Summary of the Scientific Assessment of the Committee for Medicinal Products for Human Use. Oncologist 2016;21:102-9.

7. Jerjian TV, Glode $A E$, Thompson LA, O'Bryant CL. Antibody-drug conjugates: A clinical pharmacy perspective on an emerging cancer therapy. Pharmacotherapy 2016;36:99-116.

8. Govindan SV, Sharkey RM, Goldenberg DM. Prospects and progress of antibody-drug conjugates in solid tumor therapies. Expert Opin Biol Ther 2016;16:883-93.

9. Garcia-Carbonero R, Supko JG. Current perspectives on the clinical experience, pharmacology, and continued development of the camptothecins. Clin Cancer Res 2002;8:641-61.

10. Thomas A, Teicher BA, Hassan R. Antibody-drug conjugates for cancer therapy. Lancet Oncol 2016;17:e254-e62.

11. Shvartsur A, Bonavida B. Trop2 and its overexpression in cancers: regulation and clinical/therapeutic implications. Genes Cancer 2015;6:84-105. 
12. Trerotola $M$, Cantanelli $P$, Guerra E, Tripaldi $R$, Aloisi $A L$, Bonasera $V$, et al. Upregulation of Trop-2 quantitatively stimulates human cancer growth. Oncogene 2013;32:222-33.

13. Goldenberg DM, Stein R, Sharkey RM. The emergence of trophoblast cell-surface antigen 2 (TROP-2) as a novel cancer target. Oncotarget 2018;9:28989-9006.

14. Cubas R, Zhang S, Li M, Chen C, Yao Q. Trop2 expression contributes to tumor pathogenesis by activating the ERK MAPK pathway. Mol Cancer 2010;9:253.

15. Stepan LP, Trueblood ES, Hale K, Babcook J, Borges $\mathrm{L}$, Sutherland CL. Expression of Trop2 cell surface glycoprotein in normal and tumor tissues: potential implications as a cancer therapeutic target. J Histochem Cytochem 2011;59:701-10.

16. Alfred Witjes J, Lebret T, Compérat EM, Cowan NC, De Santis M, Bruins HM, et al. Updated 2016 EAU Guidelines on Muscle-invasive and Metastatic Bladder Cancer. Eur Urol 2017;71:462-75.

17. Rouprêt $M$, Babjuk $M$, Compérat $E$, Zigeuner $R$, Sylvester RJ, Burger $M$, et al. European Association of Urology Guidelines on Upper Urinary Tract Urothelial Cell Carcinoma: 2015 Update. Eur Urol 2015;68:868-79.

18. Siegel RL, Miller KD, Jemal A. Cancer statistics, 2016. CA Cancer J Clin 2016;66:7-30.

19. Loehrer PJ Sr, Einhorn LH, Elson PJ, Crawford ED, Kuebler $P$, Tannock I, et al. A randomized comparison of cisplatin alone or in combination with methotrexate, vinblastine, and doxorubicin in patients with metastatic urothelial carcinoma: A cooperative group study. J Clin Oncol 1992;10:1066-73.

20. von der Maase $H$, Sengelov L, Roberts JT, Ricci $S$, Dogliotti $L$, Oliver $T$, et al. Long-term survival results of a randomized trial comparing gemcitabine plus cisplatin, with methotrexate, vinblastine, doxorubicin, plus cisplatin in patients with bladder cancer. J Clin Oncol
2005;23:4602-8.

21. Bellmunt J, von der Maase $H$, Mead GM, Skoneczna I, De Santis M, Daugaard G, et al. Randomized phase III study comparing paclitaxel/cisplatin/gemcitabine and gemcitabine/cisplatin in patients with locally advanced or metastatic urothelial cancer without prior systemic therapy: EORTC Intergroup Study 30987. J Clin Oncol 2012;30:1107-13.

22. Vlachostergios PJ, Jakubowski CD, Niaz MJ, Lee $A$, Thomas C, Hackett AL, et al. Antibody-Drug Conjugates in Bladder Cancer. Bladder Cancer 2018;4:247-59.

23. Ferlay J, Soerjomataram I, Dikshit R, Eser S, Mathers $\mathrm{C}$, Rebelo $\mathrm{M}$, et al. Cancer incidence and mortality worldwide: sources, methods and major patterns in GLOBOCAN 2012. Int J Cancer 2015;136:E359-86.

24. Cancer of the Breast (Female) - SEER Stat Fact Sheets [Internet]. Available at: http://seer.cancer.gov/statfacts/ html/breast.html. [Accessed: September 15, 2018.

25. Cardoso F, Costa A, Senkus E, Aapro M, André F, Barrios $\mathrm{CH}$, et al. 3rd ESO-ESMO International Consensus Guidelines for Advanced Breast Cancer (ABC 3). Ann Oncol 2017;28:16-33.

26. Ocean AJ, Starodub AN, Bardia A, Vahdat LT, Isakoff SJ, Guarino M, et al. Sacituzumab govitecan (IMMU132), an anti-Trop-2-SN-38 antibody-drug conjugate for the treatment of diverse epithelial cancers: Safety and pharmacokinetics. Cancer 2017;123:3843-54.

27. Loganzo F, Sung M, Gerber HP. Mechanisms of Resistance to Antibody-Drug Conjugates. Mol Cancer Ther 2016;15:2825-34.

28. Cocco E, Varughese J, Buza N, Bellone S, Glasgow $M$, Bellone $M$, et al. Expression of tissue factor in adenocarcinoma and squamous cell carcinoma of the uterine cervix: implications for immunotherapy with hl-con1, a factor VII-lgGFc chimeric protein targeting tissue factor. BMC Cancer 2011;11:263. 